It appears, after all, so far at least as these two books are concerned, that there is some truth in the statement of Epıphanius ${ }^{1}$ that the transiators worked in pairs. The greater part of the story told by that Father ${ }^{2}$ of the translation and the cells is wildly extravagant and improbable. But his statements with regard to the parrs of translators deserve quotation. They were, he says, shut up two and two in thirty-

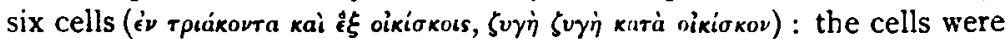

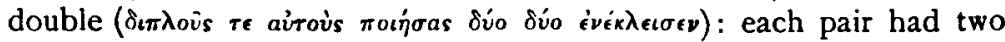
servants to cook for them, and shorthand writers, and so on. Then comes the noteworthy statement that to every pair was assigned one

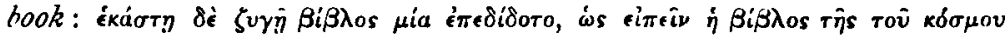

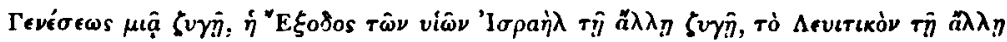

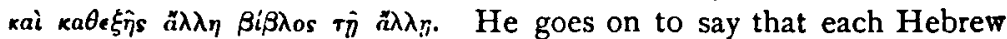

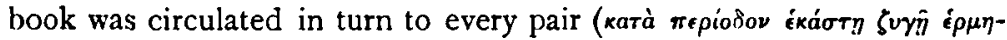

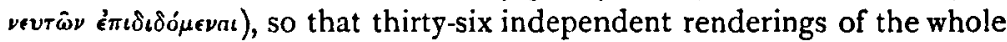
Bible were produced, which were found to agree in the minutest details! In spite of the fabulous accretions which are attached to it, it certainly looks as if in the statement that 'to each pair was assigned one book' we have a tradition, with an element of truth in it, which survived into the fourth century. How far the statement may be applicable to other books of the Greek Bible is a question which awaits further investigation.

H. St. J. Thackeray.

\title{
ON SOME EARLY MANUSCRIPTS OF THE GREGORIANUM.
}

THE notes on which the following paper is based were taken during the first half of the year 1895 , a considerable portion of which was devoted to a minute examination of the mass-books of an earlier date than the tenth century in the Vatican Library, the Biblothèque Nationale, and at Cambrai. The object was personal: viz., if possible to satisfy my mind in regard to a certain number of questions on the answers to which must depend the history of public worship and sacred rites in Western Europe from the sixth century to the tenth. As, for instance, these: ( $I$ ) is it possible to recognize with certainty the Gregorianum in the actual state in which it was sent by Pope Hadrian to Charles, and to define with exactness its contents? (2) If so, what

1 Dr Redpath recalled the story to my mind.

In De mens. et pond. 3 ff. A fragment only of the story is quoted by Wendland in his edition of Aristeas, p. 139 . 
MSS present that text in its most authentic tradition and purest form? (3) What is to be thought of such books as e.g. the Gregorianum of Ménard; can they be said to represent in any degree better the mass-book, and practice, of Rome about the year 800, than did (say) the missals of Auxerre or Beauvais, Sens or Paris in 1760? (4) The exact nature and text of Greg. thus determined, in what sort of relation does it stand to Gelas.; and, in particular, were these two books ever in use at the same time in Rome, or did the one displace the other, as, say, the Second Prayer Book of Edward VI displaced the First? (5) In what degree can the use of Greg. be traced in the extant MSS of both types of Gelas. viz. the earlier type represented by the Vatican MS, or the later type which I have called 'the eighth century recension'; or traced even in 'Gallican' and 'Mozarabic' books? (6) Finally, by what steps, in exact detail, did the book consisting of the Gregorianum and the Carolingian Supplement come to take the form presented by the type of missal common in the eleventh and twelfth centuries ${ }^{1}$ ?

The interest attaching to these investigations is not merely liturgical. Much more than this is in question, and much that to many persons

1 I may be allowed to say in explanation that my regretted friend Dom S. Baumer and I had planned a history of the mass in the West in which we hoped to trace definitively at least the main lines of its development from the fifth century to the thirteenth when, with the establishment of the Uses, the interest of the subject (except on its rubrical side) so greatly lessens. An article in the Zettschrift f. Kath. Theologie (1892) on the Stowe Missal, and one in the Histonsches Jahrbuch (1893) on the external history of the Gelastanum, were the first of a series of papers in which we designed, as a prelude, to bring successively into prominence, and, if possible, under discussion, some points of liturgical history which, it seemed, had remained unnecessarily obscure. The premature death of Dom Bäumer (1894) put an end to a project which it was beyond my unaided powers to attempt to execute, but not to my curiosity in regard to those portions of the work which would, I think, have fallen in the main to my share. I must mention the name of another friend, a man of the highest promise, who has passed away so young-Adalbert Ebner, Domvicar at Eichstatt. In reply to a communication which reached him 'am Feste des hl. Gregor,' and gave particulars as to the Vat. MS Reg. 337 which he had been unable to see, he wrote me from his bed of suffering a letter 'in festo S. Benedicti 1895 ' briefly indicating his ideas for $\{$ ii of the 'Untersuchungen' of his Iter Italicum (p. 373 seqq.) dealing with the classification of the MSS, and his difficulties. He was not sufficiently recovered to write again untıl May 7 , by which date I had made progress with my work in Pans. For every reason I felt thereafter that I could do no better than communicate to him such knowledge as I had gained. An endeavour at that time to give an account of the MSS of Greg. in the only periodical likely to be open to such technicalities was vain; on my return to England other interests absorbed attention, and as Ebner's book was published next year, I was only too ready to let the matter sleep, so far as I was concerned, and I desired to leave the work to be completed by those who had easier access to the MSS, and could better command attention, than I : a prospect which Ebner's death has greatly clouded. 
may appear more interesting. They involve the elucidation of one of the most instructive and least known chapters of Merovingian history which will, perhaps better than any other single line of inquiry, exhibit the gradual process of preparation for the Carolingian revival with its Roman aspirations of every kind and preference for Roman models; and will show that this was no sudden outburst, but the result of a movement that with slow but sure steps had been maturing for nearly two centuries. But the proof of all this for the assurance and the purposes of the historian can be given only after much detailed technical work on the part of the liturgist. The aim of the present note is to make some slight contribution to this object by an attempt to answer the first question raised above, so far as the MSS investigated by me, in combination with the descriptions of others by Delisle and Ebner, will allow.

The MSS that I have examined for the purpose fall into two classes :

I. Those which contain the Gregorianum ${ }^{1}$ only, without the Carolingian Supplement: viz. the Cambrai MS ${ }_{1} 6_{4}$ (old numbering, 159) written for the Church of Cambrai in the episcopate of bishop Hildoard, 790-816 (see Delisle, note 2 of the last page of Mémoire sur d'anc. Sacr.); and the Paris B. N. lat. 2292 (Delısle, op. cit. No. xxiii), presented by bishop John of Arezzo to the abbey of Nonantola, near Modena, about the seventh decade of the ninth century. These MSS will be designated $\mathrm{Ca}$. and $\mathrm{Non}$. respectively.

II. Those which contain Greg. and the Carolingian Supplement. These MSS contain also much additional matter, generally by other and later hands. Such additions are of primary importance for the history and development of the missal from the ninth to the eleventh century, for they lay bare the economy of later mediaeval liturgy, in Missal, Ritual, Pontifical. The MSS to be reviewed are: Vat. Regin. 337 (Reg.); Vat. Ottobon. 313, from Paris, Delisle No. xxxv (Ott.); Paris B. N. lat. 1 2050, the missal of the priest Rodradus, Delisle No. xxi1 (Rodr.); Paris B. N. lat. 281 2, from Arles, Delısle, No. xxxvi (Arel.); Paris B. N. lat. 9429, from Beauvais, Delisle No. lii (Belv.). All these MSS are assigned to the ninth century except Belv. which is stated to be of the tenth?

1 In using the terms Gregonanum and Gelasianum I do not wish to beg questions While believing that both do represent substantially what is the truth. I would gladly use any conventional designations that might be agreed on. See the last two pages of the article on Gelas. in the Hist Jahrb.; which, indeed, are only a German transiation of an English original.

2 The following MSS described or mentioned by Delisle and Ebner Iter Italicum, not examined by me, may (and some certainly do) contain Greg. as found in the MSS mentioned in the text: I. Autun, Seminary Library, MS ig bis, Delisle, No. xvi. 
As $C a$. is practically unknown, and Rodr. presents features of special interest, some observations on these two books are necessary before proceeding further. $\mathrm{Ca}$. is at once distinguished from every Carolingian Sacramentary that I have seen, or found described (except the later Cambrai MS ${ }_{162-163}$, old numbering 158 , also saec. ix), by the shape of the volume, tall and narrow, nearly three times as high as broad ( $295 \times$ ro3 millim.). The original MS consists of ff. $35^{\mathrm{b}}-203$; ff. $2-35^{\mathrm{a}}$ and 204-245 comprise supplementary matter added by various hands in the ninth century. Though of mean appearance compared with its congeners, this MS was intended, so far as the ideas of the Cambrai School ${ }^{1}$ could go in that direction, as a 'Prachtexemplar.' In the

2. Rheims, Town Libr., MS 320-272 (213 [E 320], I believe, of the present catalogue), Delısle, No. xxi. 3. Le Mans, Town L.br., MS 77 , Delisle, No. xxxi. 4. Florence, Laurentıan Libr., MS Aedıl. I 21 , Delisle, No xlıx; Ebner, pp. 29-30, 385. 5. Verona, Chapter Libr, MS xcı, Delisle, No. xxvi ; Ebner, pp. 290-29r. 6. Verona, Chapter Libr., MS 1xxxvi, Delisle, No xxv; Ebner, pp. 286-288. 7 Manz, Seminary Libr. Ebner, p. 388. 8. Cologne, Cathedral Libr., MS I37, Delisle, No. xxxix; Ebner, p. $3^{83}$. 9. Donaueschingen, MS 19I, Delisle, No. xli In company with Dom Baumer I saw this MS some eleven or twelve years ago, but cannot remember its arrangement; I doubt if it can be of so early a date (c. 830) as he is disposed to assign to it. There is a possibulity that Io. Monza, MS in the Treasury, Ebner. p. 105 ; 11. Chapter Libr. $\frac{\text { C. } 19}{100}$, Ebner, p. 107; and 12. one of the Essen MSS at Dusseldorf (Delisle, No. xl ; see Băumer in Hist. Jahrb. 1893, p 258), may belong to this class; as would also 13. the Senlis Sacramentary, Paris Bibl. de Ste Geneviève, MS Latin BB. 20, Delisle, No. xxxi, but for the displacement of the ordinations (evidently a gallicanized set) which are placed between Mur. ii, col. 240, and the prefaces.

1 The days were long since past when (as Traube says, Perrona Scottorum in Stteungsber. d. kgl. bayer. Akad., phil.-hist. Classe, 1900, p. 493) Péronne, S. Riquier, Corbie, those three monasteries on the Somme, were literary centres animated by a common Irish spint. When the Cambrai MS $16_{4}$ was being written, Corbie under Adalhard, and S. Riquer through Angilbert, looked to Rome, not to Ireland, for their culture, and the representation of Irsh influences in those quarters had passed to Cambrai. Thus the most ancient extant MS of the 'Hibernensis,' still at Cambral, was written there during the episcopate of Hildoard's predecessor Alberic $\left(+79^{\circ}\right)$; a MS now at St. Petersburg (Q. in 5), for the most part also excerpts from the Canons, contains a set of twenty verses (printed $M$. $G$. Poet. Latin. i $4 \mathrm{II}-4^{12}$ ) which the Irishman Dungal addresses to Hildoard, in which he describes himself as 'exiguum et famulum . . . tuum.' It is not improbable that the long letter from Dungal (first printed by Jaffe from a Harl. MS, and since by Dámmler in $M$. G. Epp. ; to a bishop not named, from whom he received an annual allowance, was addressed to Hildoard. Another St. Petersburg MS (F. 1 7 , saec. vii1) contains an 'Egloga' from St. Gregory's Moralia of Lathcen filus Batth (! the Irish prince, s. vii), see Neues Arhiv, v 246 . Did this also come from Cambrai? I may be consıdered as giving way unduly to imagination if, remembening the literary jealousies, friendships, and coteries in the days of Charles and Lewis, I suggest that, whilst the Carolingian Supplement is naturally found at S. Riquier, its absence is as natural at Cambra (the solitary 'Scottic' MS at S. Riquier early 
centre of ff. $35^{\mathrm{b}}, 3^{6}$ and 37 over a space $220 \times 72$ millim. surrounded by red lines, the vellum is purple; $f 35^{\mathrm{b}}$ offers the title in gold and white characters, disposed in fourteen lines as follows, the words or parts of words printed in italics being in gold: ' $\mid$ In nomi|ne dni hic sa|cramentor $\bar{v}^{1}$ | de circulo | anni| exposito | a sco Gregorı | Papa Roma|no editū | ex authen|tico libro | Bibliothecae | cubıcul s|criptum.' The rest of f. $35^{\mathrm{b}}$ and ff. 36,37 are occupied with the Canon (to 'miserere nobis' inclusive Mur. ii 60). On f. $203^{\mathrm{a}}$ at the end of the 'Oratio ad ordinandum pontificem' (Mur. ii 271-272) after five lines blank is the following colophon (already printed by Delisle) on alternate lines, in red, by the usual rubricist of the MS, traced in a character that grows larger and more emphatic as he proceeds: Hildoardus | praesul. anno | xxi1. sui onus | episcopatum | hunc libellum | sacramentorum / fieri promul|gauit. The date commonly assigned as that of Hildoard's accession to the see of Cambrai is 790 ; if this be correct the MS would date from 811 or 812 ; it cannot be later than 817 , when Halitgar was already bishop. Hildoard's last known act was to obtain from Lewis the Pious a confirmation of the possessions of his church dated April 15, 816; his death 1s, again, commonly assigned to July 4 of that year. In any case the MS of

in the nunth century, Traube, p. 529 , was probably a relic of the old fonds). The comparatively poor and mean form and style of the two sacramentaries at Cambral suggested at once when I saw them the usual character of the more ordinary Irish codices. The initials, neat, and of good effect from their mere lines, will doubtless tell their tale to the expert; although I notsced in MS 164 but one intial of the common Irish type with dots, fol $175^{\mathrm{b}}$.

1 It is impossible here to discuss the question what was the precise text of the title of the book sent from Rome. But the evidence of $\mathrm{Ca}$. on this point is not to be lightly dismissed. The 'liber sacramentorum ' of most MSS is not improbably a correction suggested by the niceness of the later Carolingian scholars, who would scout a 'Hic 'or 'Incipit Sacramentorum.' The noun on which this genitive depends is commonly suppressed in the earliest liturgical documents : 'ordine quo in Sacramentorum continetur,' Ordo Rom. 1 , \$ 32, cf. $\$ 39$; 'sicut in Sacramentorum commemoratur, Angouleme Sacramentary B N. lat. 816 (hereafter called 'Ang.'), f. $47^{\circ}$, cf Muratorl, i1 $4^{\circ}$; S Amand ordo in Duchesne Ongines, $2^{\circ}$ éd. p. 459. $3^{\circ}$ p. 476. The 'Incipit Sacramentorıum' of Non. (see Delisle, No. xxiit) is probably only a scribe's correction of the MS before him (the ' 1 ' is inserted, small, in the lower member of the ' $R$ '); 'Sacramentonum' is a form I do not remember to have seen in $s$ ix documents. Cf. 'Explıcit Sacramentorum a S. Greg. pp Rom. aeditum' in the Modena Sacramentary (Ebner, $p$ 96); this evidently goes back on the Hucusque preface only, and has no independent value as testimony. Note also how the colophon of $\mathrm{Ca}$., like the Hucusque, calls Greg a 'libellus' not a 'liber.'

- The prayer Praesta (= Gelas. ii 93, first coll.) appears in Mur. 11272 only through a mistake; it is written in Reg. by a later hand to fill up the last five lines of the page. It does not appear in any other MS I have seen; but Arel., as well as $\mathrm{Ca}$, leaves a space of five blank lines here. Praesta seems to be found after the 'Orat. ad ord. pont.' in the Modena MS (Ebner, p. 96,. It is no part of Greg. 
Greg. which he caused to be written ${ }^{1}$ is the earliest copy yet known. It seems hardly open to doubt that this 'libellus sacramentorum' is the only Frankish example still in existence (the case of Non. is different as will be explained later) of the missal used by those persons (and the writer of the Hucusque preface tells us there were such) who thought the Carolingian Supplement 'superfluous' and 'not necessary,' did not need it and did not have it, but were content to 'use only' the 'opusculum' of the 'blessed Pope Gregory.' The interesting question arises whether Hildoard's MS derives directly or indirectly from the identical Gregorianum sent into France by Hadrian before it received its Frankish supplement. I have been able to find nothıng whatever in the MS proper to supply an answer one way or the other, or to take it (for textual and critical purposes) out of the category of MSS which derive from a date subsequent to the addition of the Supplement, and I believe we must be content not to know ${ }^{2}$. So far as its text is concerned, it abounds in solecisms and grammatical errors ${ }^{7}$; of these, however, the 'anno xxii sui onus episcopatum' is one somewhat too extravagant to be taken as a fair specimen. Instances of the scribe's carelessness, too, are not uncommon 4 . Still, when all deductions are made, this MS, as I hope may appear later, will be found of primary value as a witness to the genuine text of Greg. as it was sent into France by Hadrian.

Rodr. is in some respects the most interesting and instructive of the early Gregonan Sacramentaries. It is not the production of an

1 The pompous 'fieri promulgavit' doubtless has no further meaning; $c f$. the 'Albericus... fieri rogavit' of the colophon of the Cambral MS of the 'Hibernensis.'

- It may be of interest to state that though divided into two volumes the Cambrai MSS 162, 163 form a single Sacramentary; vol. 1 contains the matter of Greg in Mur. in I-I $3^{8}$ with a body of masses of common of saints at the end; vol. il presents a fusion of the rest of Greg. and of the Supplement in an order 1 have not noticed elsewhere. The general character of this Sacramentary is perhaps sufficiently indicated by the fact that it has twelve lessons on Holy Saturday (cf. the eighthcentury recension of Gelas. in Wilson, Gelasian Sacramentary, pp. 334-33.5). These volumes present doubtless the next stage of the development of Greg in the Church of Cambrai.

'Commonly 'oratione' for 'oratio'; 'incipiunt orationes cotıdianas'; 'uigilia adsumptio S. Mar.'; but these things are much more common in Carolingian texts than appears from our smooth prints. The study of the Sacramentanes from this point of view would probably repay the philologist. For the 'ad complendum' of the other MSS of Greg., Ca. regularly uses the form 'ad completam'; but once, f. $70^{\circ}$, 'ad coplb.'

'For instance : 'et oblationem' for 'et oratio'; omıssion of 'Iohannis Thome Iacobi' from the canon; of 'Per Christum Dom. nostrum' before 'Per quem haec omnia' at close of canon, of 'nostris' after 'debitoribus' in the Lord's Prayer; of 'spiritum sapientiae et intellectus ' in the prayer 'ad inf. consignand.' (Mur. c. 6j); 'post velandum altare' (for 'velatum '). 
official scribe; nor is it written for some solemn church; nor does it represent the needs (or fancied needs) of a young Levite, brought up from childhood in the routine of a cathedral school, when about to receive the order of priesthood and use the missal for the first time himself. Rodradus was a man of mature years, seemingly of easy means; whether a layman or a cleric long in orders who hesitated to take upon himself priestly responsibility, is not certain; but certain it is that he was a man whose scruples could be overcome only through the exercise of extreme pressure on the part of his bishop: 'victus Hilmeradi antistitis (of Amiens) iussionibus, et vinctus episcopalis auctoritatıs excommunicationibus,' as he hımself says. In Rodradus's missal Greg. (ff. $19^{\mathbf{b}}-\mathrm{IO}^{\mathrm{a}}$ ) with the Supplement and its preface (ff. $\mathrm{IO}^{\mathrm{a}}-20 \mathrm{I}^{\mathrm{a}}$ ) are kept separate and intact; there follows (ff. $201^{\mathrm{b}}-24^{\mathrm{b}}$ ) a body of additional matter which shows how prayers and formularies endeared to the Frankısh clergy by long habit ('cui animo sedent') came back in the ninth century with ever increasing volume into public use; and what a devout person like Rodradus who accepted the burden of the sacred ministry only with fear and trembling-' ' trepıdus suscepi' are his words-thought in the year 853 'necessary' (so far as his mass-book was concerned) for its performance'.

In comparing the MSS to be reviewed, it will be convenient to consider first the portion of Greg. in Muratori i1 7-138, 240-272; and only afterwards the forms of ordination and their position in the MSS. Reg. as being printed in Mur. affords the simplest and easiest means of comparison ${ }^{2}$.

I. In Ott. the prayers are the same, and in the same order, as in Reg., except that :

(a) it adds to the mass of Passion Sunday a 'super populum' Da nobis quaesumus Dne perseverantem (Mur. col. 47 , note $o$ ); this is the

${ }^{1}$ Ff. $201^{b}-24^{8}$ comprise roughly : ordinations, ff. $20 \mathrm{I}-204$; votive masses (Trinity, Wisdom, \&c.), ff. 205-207; masses for vigil and day of the new feast of All Saints, a common of evangelists, ff. 208-209; masses for various occasions like those at the end of Book in of Gelas., ff. 210-216; masses for dead, ff. 21 7-219; proper masses of Saints, largely from Gelas., ff. 220-228; common of Saints, ff. 228-233; masses, again, for special occasions and of a personal cast, ff. $234^{-2} 4^{2}$; a collection of 'apologiae sacerdotis,' ff. 243-245; finally, a long 'Ordo ad visitandum et inungendum infirmum,' ff. $24^{6-248 . ~ A t ~ f o l . ~} 222^{2}$ is a mass of Invention of Holy Cross, with a long preface, which affords a good example of the way in which the barbarism of Merovingian liturgical composition was corrected in Rodradus's more cultured days; the onginal text of this preface is to be found in the Angouleme Sacr. Paris B. N. lat. 816, f. $69^{*}$ (Rodradus, or the corrector whom he copied, has changed 'culus ligni mysteris saluarı credimus omnes' of the Ang. text into 'c. l. mysterio saluari nos credimus').

${ }^{2}$ It is well to state that in Reg. Muratori's col. 241 immediately follows his col. $13^{8}$.

VOL. IV.

E e 
'super populum' of the following Tuesday in Reg. and also in Ott. itself.

(b) it adds on Palm Sunday a 'Benedictio in Palmis' Deus cuius Filius pro salute (c. $5 \mathrm{I}$, note $z$ ); I cannot trace this further back.

(c) it adds a 'super populum' Purifica $q$. Dne to the mass of Palm Sunday (c. 52, note $b$ ); this is the 'ad populum' at this day in Gelas. (c. 546), and in the eighth-century revision of Gelas. (Wilson, p. 332, Ang. f. $32^{\mathrm{a}}$ ).

(d) it adds to the 'orationes pro peste' (better, according to the MSS, 'or. de mortalitate') a prayer entitled 'super oblata' Subveniat nobis (c. 269, note $k$ ); this is the 'secret' of the mass 'tempore quod absit mortalitatis' in Gelas. (c. 712), and eighth-cent. Gelas. MS R. (Wilson, p. 369, and Gerbert, p. 305, there referred to), Ang. f. $165^{\text {a, }}$ and Paris B. N. lat. 2,296, f. $\mathbf{4 2}^{\mathrm{a}}$.

II. In $C a$. the prayers are the same, and in the same order, as in Reg., except that on the Epiphany the seventh 'alia oratio' Illumina and the ' super oblata' Ecclesiae tuae (cc. 18, 16) exchange places in Ca.

Moreover, according to my notes, $\mathrm{Ca}$. does not contain the prayer Salutaris tui of the mass of the Monday of the first week of Lent (c. 3I), and the prayers of the mass of Thursday of that week are Devotionem, Suscipe q. Dne (see Pamelius, ii 221), Sacrificia q. Dne, Tuorum nos instead of Devotionem, Sacrificia q. Dne, Tuorum nos, Da quaesumus (cc. 32-33). But I think it is most probable that the MS itself is in these two latter cases like Reg., and that I have here blundered ${ }^{2}$.

III. In Rodr. the prayers are the same, and in the same order, as in Reg., except that :

(a) Fifth week of Lent, Saturday, for 'super obl.' Cunctis nos (c. 5I), Rodr. f. $47^{\text {a }}$ has Praesta q.o. D. ut ieiun.; this latter in Gelas. (c. 53I) is the 'secret' of Wednesday, but of Saturday in saec. viii Gelas. R. and S. in Wilson, p. $33^{2}$; Ang. f. $3 \mathrm{r}^{\mathrm{b}}$; Godelgaudus, in U. Chevalier Bibl. Liturg. vii p. 323 .

(b) Assumption, for 'sup. obl.' Subveniat (c. 114) Rodr. f. $75^{\text {b }}$ has Intercessio q. Dne b. Mariae; and Subveniat follows as 'alia.' Intercessio (which in Gelas. is the 'secr.' of masses of St. Fabian, and St. Rufus, cc. 638,664$)$, adapted, is made the 'secr.' of Assumption in s. vili Gelas. (R. and S. in Wilson, p. 353 ; Ang. f. $87^{\mathrm{a}}$; Godelg. p. 340 ; B. N. lat.

\footnotetext{
1 In investigating Ca., I was only able to use Pamelius; when rendered back to $R e g$. the notes thus taken of the contents of the MS, apart from the inversion of the two Epiphany prayers (where a mistake could not creep in), exactly reproduce Reg. except in these two cases, in the first of which I may easily have noted that the MS has 'prayers I, 2, 5' of Pamelius instead of ' $1,2,4,5$,' and in the second ' $1,2,3,4$ ' instead of ' $1,3,4,5$. ' In this latter case the incipits show how a mistake may easily have arisen.
} 
$2296, f_{1} 22^{b}$ breaks off imperfect in the mass of the Assumption, but begins with the collect Concede as R., S., Ang., and Godelg.; Concede is the Ambros. 'super sind.' for Assumption.)

(c) SS. Cornelius and Cypr., for 'super obl.' Adesto (c. I I9) Rodr. f. $77^{\text {h }}$ has Plebis tuae Domine munera, Adesto being made an 'alia' collect. This is the arrangement in Ang. . $^{9^{2}}$, and apparently in S.

(d) The mass of Exalt. of $\mathbf{H}$. Cross found in Reg., Ott., \&c., has caused trouble in more than one MS. It is enough to read the first line of the 'super obl.' Iesu Christi Dni n. corpore saginati to see that the prayer is an 'ad complendum.' The present Roman missal has overcome the difficulty by reading in accordance with good sense but counter to all ancient authority 'saginandi.' Rodr. has adopted more radical measures, but also done better, by making $J$. C. D. n. c.s. a first 'ad compl.' and that in Reg., \&c., a second. For 'super obl.' Rodr. has adopted the 'secr.' Devotas of the mass of Exalt. of $\mathrm{H}$. Cr. in Gelas. (c. 667) and s. viii Gelas. (R., S., in Wilson, p. 356, Ang. f. $\left.92^{a}\right)^{1}$.

(e) At f. I $^{\mathrm{b}}{ }^{\mathrm{b}}$ Rodr. inserts between the 'oratio ad ordinand. pont.' (cc. 271-272) and the Hucusque preface to the Supplement, with the rubric ' $v$ non. mai. Inuentio s. crucis' the mass for that feast in Gelas. cc. $645-646$ which is also simply adopted in s. viii Gelas. ${ }^{2}$

( $f$ ) Finally, in the 'Orationes pro peccatis' the prayer Praesta at the head of col. $25^{\circ}$ of Mur. is placed in Rodr. after Exaudi, the third prayer of that col.

The case seems clear: not merely is $R$ eg. in all these items supported by $\mathrm{Ca}$., Ott., \&c., but the changes in Rodr. evidently show themselves to be so many instances of the discarded Gelas. (and, as appears from (a) above, the eighth-century recension, not the earlier form) asserting itself even in a text which professes formally to be a copy of Greg.

IV. In Belv. ${ }^{3}$ the prayers are the same, and in the same order, as in Reg., except that :

(a) it omits the special preface Qui ut de hoste (c. 9) for the mass 'ad sanctam Anastasiam' on Christmas Day.

(b) it omits the fifth and sixth 'aliae orationes' of that feast, O. s. D.qui hunc diem, D. qui hum. subst. (c. 11 ).

V. Arel.-I did not examine this MS prayer by prayer, but only noted the order of contents according to the rubrics; this order is that of Reg.

1 The s. viii Gelas. (Wilson, p. 356) probably gives a clue to the solution of the difficulties; but this is a matter that cannot be dealt with now.

${ }^{2}$ In Rodr. this same mass for the feast of the Inv of $\mathrm{H}$. Cr. (the absence of which from Greg. seems to have been keenly felt in the Gallic lands) is repeated later with a special preface (see supra, p. $4 \mathrm{I} 7$, n. I).

${ }^{3}$ Two leaves are missing between ff. 77 and 78 (from tribue bentgnus, Mur. c. 246 , to popult tut ne plus, c. 250). 
VI. Non.' shows the following differences from Reg.:-

(a) for the mass 'in Oct. Dom.' and 'or. in alia dominica ' (cc. 15-16) are substituted 'Dominica prima post natale Domini,' 'Dom. $2^{\text {a }}$ p. n. D.' (cf. Supplement in Mur. cc. 158-159); and after the Epiphany, separately intercalated among the feasts of Saints, are Dom. I to 6 'post Theophan.' (ibid. cc. 159-161). The compiler of the Supplement (which is not contained in Non.) derives these six masses from s. viii Gelas. which, for its part, largely uses in them Greg. material. The subject of the Sunday masses of Non. will be again adverted to when the North Italian group of Greg. MSS is considered later.

(b) The masses of St. Agatha and St. Valentine are omitted.

(c) Between Nativ. B. V. and SS. Prot. et Hyacinth. (c. II8) a mass 'S. Gorgonii mart.' is inserted (so too in s. viii Gelas. MS S., Wilson, p. 355, and Ang. ff. $9^{1-92}$; Gorgonius is a Gelas. feast, col. 667 ).

(d) The order of the masses of Sept. 14, SS. Cornel. and Cypr. and Exalt. S. Cr. in Greg., is inverted in Non., and precedence is given to Exalt. S. Cr. as in saec. viii Gelas. MS S., Wilson, p. 356, and Ang. f. $\mathbf{9 2}^{\mathrm{b}}$. In MS R. the mass of SS. Corn. and Cypr. is suppressed, and Exalt. S. Cr. is alone honoured on this day.

(e) On Sept. 16 the mass of St. Euphemia is given under the combined title 'Nat. S. Euphem. uirg. Lucie et Geminiani,' and the mass of SS. L. and G. in Greg. is omitted in Non. I know of no other instance of this arrangement.

( $f$ ) The September Ember days and the 'die dom. vacat.' mass (cc. 122-124) are omitted (see below, p. 424, note 3).

(g) Before SS. Cosm. and Damian (c. 124) are added masses of the vigil and feast of St. Matthew, and of St. Maurice and Companions; after St. Mark Pope (c. 126), a mass of St. Denis ; between St. Calistus and St. Caesarius (c. r 26), masses of St. Luke, and of the vigil and feast of SS. Simon and Jude, and of vigil and feast of All Saints.Of these, the masses of All Saints date from the ninth century; that of St. Denis may (just possibly) be of some interest in reference to the origin of the MS ${ }^{2}$; the text of those of SS. Matthew, Simon and Jude, and Luke, is the same as in MSS R., S., and Ang. of s. viii Gelas. I know of a mass of St. Maurice only in Ang. f. $94^{\mathbf{a}}$, but the prayers are different (St. Maurice is also in the Missale Gothicum, in the Ambrosian, and in the Padua MS, Ebner, p. 127).

(h) Several masses throughout the volume have special prefaces.

1 A leaf is missing between ff. 34 and 35 (from 'ad compl.' of 'fer. vi,' Mur. c. $3^{8}$ to c. 40, line $7, a b$ imminentibus).

A space of two lines left for the rubricist was never filled in; and the first line of the collect is in red. 
(i) Finally, the 'oratio ad ordinand. pont.' (Mur. cc. $27 \mathrm{I}-272$ ) is incorporated among the forms of ordination.

Thus, though the prayers and order of Greg. as found in $\mathrm{Ca}$., Reg., Ott., Rodr., Belv. (and Arel. as limited above) are still preserved in Non, this MS shows a further stage in the process of incorporating Gallican-Gelasian matter into Greg.

In regard to the forms of ordination of Greg. and the place assigned to them, the following is the evidence of the MSS examined.

In Ca., Reg., Ott., Rodr., they are those given in Mur. ii cc. $357-361$, and they are placed between the Canon (cc. 1-6) and the masses (c. 7 seqq.).

This was also the order in Belv. when that MS first left the hands of the copyist ; but changes were immediately made which obscure though they do not obliterate the original features. The MS in its present mutilated state begins with the words 'ab eterna damnatione' of the Canon (c. 3), which is contınued almost to the end of f. 2, where after Agnus Dei, \&c. (as Mur. c. 6), in the same line is the rubric 'Benedictio episcoporum,' and there follow on the rest of this page and on ff. 4 and 8 the forms of ordination, Mur. ii $357-361$, in their proper sequence, and with their text intact. On ff. 3, 5, 6 and 7 are inserted by, as I think, the same scribe and rubricist, forms for minor orders as follows: ff. 3 and $5=$ Mur. ii c. 405 (Ostiarius cum ordinatur to end of c. 408 ), and then 'Capitulum S. Gregorii' Sicut qui invitus to ac manutergium (Ménard, p. 234; Migne P. L. 68. 219-220); f. 6a.b 'Ad subdiac. ordınand.' Exhibeatur in conspectu to consequatur (Ménard, pp. 234-235, c. 2 ; Migne, c. 220); there immediately follows, in the last two lines of f. 6b, the title 'In nomine Domini. Incipit,' \&c., continued on f. $7^{\mathrm{a}}$, as in Mur. c. I to dignum et iustum est. These inserted non-Greg. ordinations go back of course to the Gallican set in Gelas. i 95, cf. 96. It would appear, therefore, that the scribe first copied Greg. as he found it before him in the order now found in Ca., Reg., \&c.

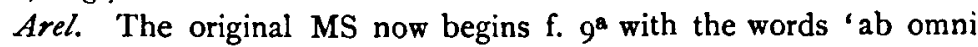
perturbatione securi' of the Canon (Mur. c. 6) and the masses follow. If the original MS when perfect contaned the ordinations they must have been placed before the Canon. The forms for minor orders, practically the same as those in Belv., are found ff. $5^{\mathrm{a}-8}$ in a hand hardly later (it would seem) than that of the original scribe.

Non. begins with the Canon, which is followed by the forms of ordination, all in the original hand, and thus disposed: the 'Bened. episc.' and 'Or. ad ordinand. presb.' as Mur. ii cc. 357-360, but the 'Or. ad ord. pont.' which is the last item in the other MSS (cc. 271-272) 
is in Non. inserted before the 'super obl.' c. 358, with, however, omission of that part of the explanatory rubric 'Or. ad . . . initium est' which would have made the insertion intelligible. After these, and under the title 'Incipit ordo de sacris ordmibus benedicendis' (cf. Mur. c. 405), come forms for orders up to subdeacon inclusive similar to those in Belv. and Arel. Then, with the title 'ad ordinandum diaconem,' the remaining Greg. form (Mur. cc. 360-361). Non. in this particular of the ordinations again shows an advance on the other MSS.

The testimony of the MSS enumerated p. 413, n. 2 supra, on the points hitherto considered, so far as it can be ascertained from the descriptions of Delisle and Ebner, appears to be as follows :-

(a) In regard to the place of the Greg. forms of ordination, they are placed between the Canon and the body of masses in Nos. I, 3, 4, 6,7 ; the masses immediately follow the Canon in 2, ro, 11 (and 13); 5 is imperfect ; as to $8,9,12$ information is wanting 1.

(b) As regards the remainder of Greg. (Mur. ii cc. 7 to $138+24 \mathrm{I}$ to 272 ) the descriptions in Delisle of $1,2,3$ (and, except the ordinations, of 13 also) raise a strong presumption that they offer the same book as Reg. No. 4 shows, according to Ebner (pp. 29, 30), the same 'arrangement and contents' as Reg., except that 'numerous prefaces have been embodied in the text.' If I rightly understand Ebner (p. 290), No. 5, imperfect, affords the same text as Reg. in Mur. cc. I 16 to ${ }^{2} 38+241$ to 272 , except that the mass of Exalt. S. Crucis and St. Nicomedes (Mur. cc. Ir9-I 20) are wanting (or is it only that a leaf is missing ?). His description of No. 6 is of course defective, yet, taking all the circumstances into consideration, it seems little doubtful that this MS is, like No. 5, a copy of Greg. of the type of MS Reg. No. 7 shows 'exactly the same disposition of its contents' as Reg. (Ebner, p. 388). As to Nos. 8, 9, 10, I1, 12 further information is required before any definite statement can be made.

The question arises whether the book thus limited is complete, or whether any other items not now found in Reg. were contained in the original MS of the Gregorianum that was sent from Rome to Charles by the hands of 'John the monk and abbot.' If the witness of the MSS is to be taken as decisive in such a question, the only items, so far as I can see, on behalf of which a claim can be raised that calls for any consideration, are contained in a group of Greg. MSS which I may call the North Italian group.

The question raised by this group of MSS is-did Greg. as sent by Hadrian comprise, besides the matter of $R e g$., a body of Sunday masses

1 In MS Bodl. Auct. D. i 20 (Delisle, No. xxxvii), though the MS seems not to agree with Reg., the ordinations (bishop, priest, deacon, only) come between the Canon and the masses. 
(after Christmas, Epiphany, Easter, Pentecost) corresponding to Nos. vii-xiii in Muratori's print of the Carolingian Supplement (coll. r58176)? Their absence from Rodr. seemed to Ménard to be so 'incredible' and 'absurd' a feature as to be a main consideration in leading him to choose for his print his 'Codex S. Eligii' (B. N. lat. I 2,05 r, Delisle, No. li), with the result of involving the whole subject of the early Roman Liturgy in confusion and darkness, and making it for subsequent inquirers a region 'ubi sempiternus horror inhabitat.' The mere fact that the compiler of the Carolingian Supplement thought proper to include in it the body of Sunday masses Nos. vii-xlii raises of itself a strong presumption that such masses were not contained in the Gregorianum as sent into France. But there is still room for the supposition that this was only an omission; and it might be urged that the 'North Italian group' of Greg. MSS, so far as their contents are yet known, countenances this supposition. The Verona MSS $9 \mathrm{r}$ and 86 may be taken as typical : immediately after the end of Greg. comes a section headed 'Incipiunt orationes ad missam diebus dominicorum' containing ' masses for Sundays after Epiphany (4 ?), (? oct. of) Easter (4 ?, 5), (? oct. of) Pentecost (5 ?), oct. of Apostles Peter and Paul (5), Lawrence (5), Michaelmas (8) ${ }^{2}$.

The Gospel capitulars of the eighth and ninth centuries show a twofold arrangement distinguished by the mode of counting Sundays after Pentecost : one class reckons simply Sundays I to 24 (or 25, 26) after Pentecost ; the other, Sundays after Pentecost, Peter and Paul, Lawrence, Michaelmas ('post S. Angeli'; some capitulars reckon 'post Cypriani' instead of 'post Angeli'). Of the two modes the latter bears on the face of it evidence of Roman origin or connexion, even if there were not actual evidence that the origin of the other is not Roman but Frankish. Not merely is this the system adopted in the eighth-century recension of Gelas. (MSS R., S., Ang., Paris MS lat. 2,296), but

1 I am obliged here to combine the information in Ebner, pp. 287, 290.

${ }^{2}$ Cf Monza, MS $\frac{F . I}{I 0 I}$, saec. ix-x : post oct. Pasch. $1-4$; post Pentec. $1-6$; post nat. Apost. I-6 ; post Laur. I-5 ('); post Angelı, I-8 (Ebner, p. I08). Padua Bıbl. capit. MS D. 47 : post Epiph. 1-4; post oct. Pasch. I-4; post Pentec. ebd. 2-5; post nat. Apost. I ; post oct. A post. 1-5; post nat Laur. 1-4; post S. Angeli, 1-9 (abrd pp. 123-127). In this MS the Sundays are intercalated among the feasts of Saints as in Greg. and saec viii Gelas. It appears to be the most interesting of all the MSS catalogued by Ebner; though (speaking with the reserve imposed on one who has not seen the MS) I cannot but think that Ebner's assignment of it to the class of the 'gregorianisırtes Gelasianum' (= s. viil Gelas.) is due to a misunderstanding. It seems to be Greg. But he is probably right (p. 380 ) in viewing it as a member (the earliest and, I would add, a most revolutionary member) of the 'North Italian group.' The Roman topographical notes are hardly a sign of the purity of the text. 
Amalar, a curious and inquiring person, leaves us no doubt on the subject. In complling his antiphonar for the Office, he found in some MSS a body of what he calls 'antiphons taken from the cotidian gospels.' No one who carefully examines and follows Amalar's treatise will, I think, fail to come to the conclusion that Tommasi $(O p p$. iv 297 seqq. and his note A) rightly identifies these with the antiphons for Sundays 1-24 after Pentecost in his St. Gall MS ('Hartker', just published in facsimile). 'As to these antiphons,' writes Amalar, 'I asked the masters (= cantors) of the Roman Church whether they sang them. "Certainly not," they replied. But our masters (in France) avouch that they received them from the first masters who taught the Roman chant within the Frankish dominions. God alone knows who are the deceivers here, who the deceived; and whether the Romans never sang them, or have simply let them fall out of use through their own negligence and indifference; in any case we sing them, not only on account of their wording (for their words are truly salutary), but also on account of the high repute of our cantors, who, in the art and practice of Church song, proudly point to their own pre-eminence '.'

The Modena MS Bibl. capit. is 7, 'saec ix to x,' shows (Ebner, pp. 94-96) a Gregorianum considerably more interpolated than Non., and considerably altered. At the end is a body of Sunday masses; those after Pentecost are numbered I-24, thus betraying the influence of the Carolingian Supplement. But in the four MSS mentioned above, these Sundays bear a distinctly Roman label. Should the text of their masses, on examination, prove to be different from that of the corresponding masses in the Supplement ${ }^{2}$, a case is made out for considerıng them really part of Greg. as used in Rome in Hadrian's time, and therefore Reg. and its congeners as, so far, incomplete. If not, they will be welcome evidence of the channels through which, and probably the form in which, the Supplement found its way south, and by-and-by to Rome. Until the necessary information is forthcoming the question must be left open ${ }^{3}$.

1 'Qui glonantur magisterio se uti cantilenae exercitationis,' Amalar. de ord. Antiph. cap. 68 . If the Roman deacon John badly lost his temper over this matter of Church song (Băumer, Gesch. d. Brevers, pp. 233-235), there was much to excuse him.

2 The whole series of the Suppl. derives directly, not from the older type of Gelas., but from the saec. viii recension.

$s$ We are now in a position to understand the economy of Non., which it may be well to explain here. The original MS ends f. I01*. A later scribe (saec. x1, I think), without the loss of a line, continues the MS with the title 'Incipiunt misse in diebus domincis a pentecosten usque ad aduentum Domini'; then follows (In more than one hand seemingly) the series Dom. 1-24, incorporating the September Ember day masses omitted by the original scribe of the MS (see p. 410 supra). The masses for Sundays after Easter do not appear in the MS. The 
But whatever the answer on the point of detail thus reserved, it is, I think, already clear that, taking into account the whole body of 'Gregorian' MSS of the ninth and tenth centuries, one class of them, and one only, preserves the Gregorianum, the actual book, sent by Hadrian to Charles, viz. that represented in print by Reg.- when, of course, that print is restored to the order of the manuscript itself, viz. Mur. ii, coll. I to $6+357$ to $36 \mathrm{I}+7$ to $13^{8}+24 \mathrm{I}$ to $27^{2}$. I would add, moreover, that from this book alone ${ }^{2}$ can the rites and formularies, and the authentic text of the prayers, in use in the Roman Church at the close of the eighth century be ascertained; and all other texts such as those printed by Pamelius, Rocca, Ménard, or presented in the whole body of known MSS of the ninth and tenth centuries, can clarm to represent the use of the Roman Church only in so far as they coincide with the MSS of the class represented in print by Reg.' At the same

omission of the Greg. Ember masses of September makes it probable that, varying the practice observed for the Sundays after Christmas and Epiphany, which are intercalated among the Saints' days, the person for whom the book was written reserved the Sundays after Easter and Pentecost (including the September Ember masses) for a special series at the end of Greg. as now found in the Verona MSS 91 and 86. Whether this series was ever actually written, and the MS has since been mutilated, must remain uncertain. Delisle, from the handwriting, considers the MS to be of French origin ; if this be so it would acquire, from the liturgical point of view, an additional interest, inasmuch as it so far departs from both the true and corrupt types of Greg. then current in France, that it must have been written under particular instructions to suit the practice of the region for which it was intended. I say nothing on the subject of the 'orationes cottidianae Gregorin papae,' printed by Ebner, pp. 318-2I, from the Padua MS, as it seems sufficiently clear that the model and original of this section is to be sought in the saec. vill Gelas.

${ }^{1}$ It is to be remembered that the Liturgra Romana vetus must have been to a laige extent a printer's speculation; and that Muratori never saw the MSS Reg. and $O t t$., but only copies sent him by his friend Giuseppe Bianchin the Oratorian; nor does it even appear that he corrected the proof-sheets of Greg with these copies, the only part of the work that is certainly his is the preface. The undertaking was looked at askance by some at least of those who had access to the MSS, and could have afforded effectual help; see Vezzosi's remarks on the Lit. Rom. vet., and on Muratori, and his work, in Thomasu $O p p$. v1, xli1-xlul. It is a pity that Vezzosı, who, as he says, often examined Reg., and corrects Muratori's number (' non 335 sed 337 '), did not, even if he must needs indulge in injurious remarks and insinuations, also point out the great mistake in the print which has misled those who have used 'Murator' from that day to this. I may add that there appears to be no ground for supposing that $R_{e g}$. is a MS written anywhere else than in France.

${ }^{2}$ Of course the Ordo Romanus must be the main source for merely rubrical directions.

${ }^{3}$ The words in the text are purposely made, both for inclusion and exclusion, as definite as $I$ can make them. I know that they go beyond what is warranted by anything adduced in this 'Note,' and recognize what the statement made implies for the history and chronology of a number of sacred rites. But I believe they 


\section{THE JOURNAL OF THEOLOGICAL STUDIES}

time it is to be observed that one valuable and useful instrument of criticism still exists, which, in points of detail, enables us to get behind all the extant MSS of Greg. This is the 'eighth-century recension' of Gelas., the important rôle of which in the evolution of Western liturgy has not as yet been duly appreciated. This work, more than anything else, not merely facilitated Charles's measures in regard to the massbook, but rendered them inevitable.

EDMund Bishop.

CHAPTERS IN THE HISTORY OF LATIN MSS. III.

\section{The Lyons-Petersburg MS of Councils ${ }^{1}$.}

THE first of the papers published under this heading in the Journal J.T.S. i. 435-441), was mainly devoted to the proof of the fact that the manuscript now classified as F II 3 in the library at St. Petersburg was identical with the two MSS 563,564 of the Jesuit College of Clermont, and further that it originally formed part of the same MS as Clermont 569, now Berlin lat. 83-the combined MS being that described by Sirmond in 1629 as the property of the Chapter of Lyons. The Petersburg MS has, through the singular generosity of the authorities of the Imperial Library, been deposited for some time in the Bodleian, and further notes based on personal inspection may therefore not be out of place in view of the great interest, both historical and palaeographical, which attaches to it.

1. The MS-that is to say, the Petersburg part of the original MSis unfortunately in a terribly damaged condition; at some period before

express the conclusion to which, as precise information increases, liturgists will come; and it is at any rate important that such a thesis should be brought, if necessary, to the test of a detarled and formal discussion on the basis of the fullest knowledge of the evidence, if, that is to say, the study of Western liturgy of the seventh to the tenth century is to emerge from its present stage of impressionism. And I am the more insistent on this point when I read (to adduce but one instance) what a writer so careful as Friedrich Wiegand, whose vision is so clear, and who sees so much, says of the Gregonanum (Die Stellung des apostolischen Symbols, \&c., i $291-3,296-7)$; in sayıng this I quite bear in mind what is said pp. 422-4 supra, as to the Sunday masses, Nos. vii-xhi, of the Supplement.

1 I must record my grateful thanks to my colleague, the Rev. H. A. Wilson, for his help in making notes for me on this MS at a time when I was too 11 to work at it myself. 